Fassin, D. (2011) Humanitarian Reason: A Moral History of the Present. University of California Press.

Kafka, B. (2012) The Demon of Writing: Powers and Failures of Paperwork. Zone Books.

Riles, A. (2006) Documents: Artefacts of Modern Knowledge. University of Michigan Press.

Strathern, M. (2000) The Tyranny of Transparency. British Educational Research Journal, 26(3): 309-321.

Waters, T. (2018) Bureaucratizing the Good Samaritan: The Limitations of Humanitarian Relief Operations. Routledge.

Weiss, T.G. (2013) Humanitarian Business. John Wiley and Sons.

\title{
Donors
}

Some three-quarters of all humanitarian funding for aid is provided by a relatively small number of, mainly Western, governments. The top three governments - the United States (USA), the United Kingdom (UK), and Germany - provide about 60 percent of this funding. The USA is the single largest contributor, providing around a third of the funding for such aid. Together, the European Union (EU) and EU member countries provide just over half of all government funding for global humanitarian aid (Development Initiatives 2018, Willitts-King et al. 2018). Countries such as China (Hirono 2018) and India (Roepstorff 2015) currently play a growing role as global humanitarian actors.

Islamic funding for global humanitarian aid is also emerging. Countries such as Saudi Arabia, the United Arab Emirates, and Kuwait, together with Turkey, are providing funding, and are among the top 20 government providers of humanitarian aid.

About a quarter of global humanitarian aid is provided by private donors. There are variations between years, with spikes likely driven by high-profile sudden-onset crises such as the Nepal earthquake or the Ebola outbreak. An estimated two-thirds of private funding comes from individuals, with the rest originating with trusts, foundations, or companies.

The donor agencies' financial contribution is channeled through a variety of organizations and often passes through multiple levels of participants to reach the people affected by the crisis. Most government funding, some 60 percent, is disbursed through multilateral organizations, primarily United Nations (UN) agencies. The World Food Programme and the UN High Commissioner for Refugees receive the bulk of this. 
Government funding is also channeled to the UN through the UN Office for Coordination of Humanitarian Affairs and its various pools. Pooled funds are intended to provide flexible funding that is responsive to changing needs and gaps in resourcing. They allow donors to contribute to collective humanitarian responses and can provide rapid assistance as emergencies develop. Two-thirds of the funding for the UN humanitarian pools is provided by five European donors (UK, Sweden, the Netherlands, Germany, and Norway).

The multilateral development banks - the World Bank, the African Development Bank, and others-also play an increasingly important role in this area. They channel funds as humanitarian assistance, and provide financing beyond humanitarian assistance to countries affected by and at risk of crisis. They have a growing range of instruments and mechanisms that seek to provide crisis financing for preparedness, response, recovery, and reconstruction.

Government donors also provide some funding to non-governmental organizations (NGOs) and international organizations, and global funds and appeals managed by such organizations. Chief among these are the International Red Cross and Red Crescent Movement. They manage two funds: one for mainly "natural" disasters and one that responds to conflict-related disasters.

Most of the private funding (9o percent) is directed to NGOS and humanitarian institutions such as the International Red Cross and Red Crescent Movement. Some NGos, for example Médecins Sans Frontières, do not accept government funding.

Very little government funding is provided directly to local institutions and organizations in the countries and regions affected by humanitarian emergencies.

Some of the UN agencies and donor agencies have their own facilities for distributing humanitarian aid, but most rely on NGOS and/or commercial service providers, and some also - where possible - use local authorities to distribute the aid (Mowjee et al. 2017).

The main problems related to the role of donors are lack of coordination during humanitarian emergencies, political interests driving the flows of funding, and the consolidation of proper accountability mechanisms. Complexities associated to donors' policies are also linked to the fact that humanitarian action has become blurred as its goals have expanded to include more developmental and peace-building aims (Macrae et al. 2002).

\section{Elling Tjønneland}




\section{References}

Development Initiatives (2018) Global Humanitarian Assistance Report 2018. http:// devinit.org.

Hirono, M. (2018) Exploring the Links between Chinese Foreign Policy and Humanitarian Action Multiple Interests, Processes and Actors. Humanitarian Policy Group Working Paper, Overseas Development Institute.

Macrae, J. et al. (2002) Uncertain Power: The Changing Role of Official Donors in Humanitarian Action. H PG Report 12, Overseas Development Institute.

Mowjee, T. et al. (2017) From Grand Bargain to Beneficiary. An Analysis of Funding Flows through the Humanitarian System. Humanitarian Policy Group Commissioned Report, Overseas Development Institute.

Roepstorff, K. (2015) India as Humanitarian Actor. Convergences and Divergences with DAC Donor Principles and Practices. In: Sezgin, Z., Dijkzeul, D. eds. The New Humanitarians in International Practice. Routledge.

Willitts-King, B. et al. (2018) Measuring the Iceberg. The Opportunities and Limits of Better Tracking of Resources beyond International Humanitarian Assistance. Humanitarian Policy Group Working Paper, Overseas Development Institute.

\section{Education}

In postwar and post-disaster contexts, national authorities, international organizations, and non-governmental organizations must provide children who have been displaced or are otherwise affected by restricted mobility, growing insecurity, lack of infrastructures, and/or qualified personnel and loss of livelihood and families with access to schooling. Schools are not safe from direct attacks during times of armed conflict. For example, in rural areas, schools may be the only permanent structures, which makes them highly susceptible to shelling, closure, or looting. Local teachers may also become primary targets because they are considered important community members, they may hold strong political views, and they may embody the only form of government representation in an isolated village. The destruction of education networks is one of the most severe democratic setbacks for countries affected by conflict. The deterioration and loss of basic education and professional skills normally takes years to replace, making the overall task of postwar recovery extremely difficult (Aguilar and Retamal 2009). As a basic principle, the 1989 Convention on Rights of the Child obliges "State parties [to] take all feasible measures to 